\title{
Sanggah Dawa in the Life of Pacung Community
}

\author{
I Wayan Patera
}

\section{Introduction}

Pacung village, Tejakula District, Buleleng Regency, is one of the old villages located in the northern part of Bali near Bangkah, Sembiran and Julah. With its specific traditions and large amount of cultural relicts still considered sacred by the community, Pacung, classified as a Bali Aga village, has been an object of research from the $1^{\text {th }}$ to the $21^{\text {st }}$ century (see Ardika, Setiawan and Rochtri, Suastika, Drawatik, Hauser-Schäublin this volume).

The findings of the researches so far carried out suggest that Pacung and the other Bali Aga villages located in the eastern part of Buleleng regency are sites that have been settled since the pre-historic era. This can be proved by the findings of Palaeolithic artefacts and pottery sherds, some local and others made in China and India. Human skeletons with grave goods have also been found, providing evidence of the belief in a life after death and worship of ancestors.

The findings of foreign pottery sherds, such as the ornamented Indian one, show that Pacung and its surroundings were settlement sites and in touch with the outside world already 2000 years ago (see Ardika this volume). The quality of the rouletted pottery of Indian origin found at Pacung was good. It is said to have come from Arikamedu in South India at the beginning of the first century AD.

The arrival of Hindu culture did not necessarily mean the extinction of the old culture or Bali Aga, whose essence is the belief in the power of nature and the 
ancestors' souls (Ardana 1986:15). Nevertheless, apart from grave goods we do not know much about the contents of pre-Hindu religion. However, there are traces of religious beliefs and practices left that differ from Indian Hinduism, such as ancestor worship. We therefore can assume that ancestor worship in Bali is a survival of pre-Hindu religion. As Koentjaraningrat stated, religion consists of five elements: the system of belief, religious emotion, a system of sites, ceremonial and ritual tools and religious worship (1980:80). This applies to all religions including ancestor worship and the worship of the natural powers (Hendropuspito 1983:34).

This article focuses on one special feature of ancestor worship in Pacung as still performed today. The data were collected through library research, survey and narrative interviews in Pacung village, and analysis of forms. A contextual interpretation will then be made, resulting in a description of the function and meaning of sanggah dawa.

One of the most interesting things in the socio-cultural life of the Pacung community, especially in their religious life, is the holy shrine (pelinggib) called sanggah dawa. There are only 14 families (out of 238 in 2007) who have such a shrine in their household temple. Most of the villagers possess a household temple with shrines that are similar to those in other parts of the island.

\section{Function and Meaning of Sanggah Dawa}

The expression sanggah dawa is derived from two words, sanggah and dawa. Sanggah refers to a group of holy buildings belonging to a family coming from the same ancestors ( $s a=$ one, angga $=$ body, sanggah = belonging to the same ancestors); dawa means 'long'. sanggah dawa is therefore the name given to a form of holy building belonging to one family. It is narrow high and long (see Photo 1). The structure of sanggah dawa consists of three parts: the foot, the body and the top with the niches (rong) including the roof. The building is $170 \mathrm{~cm}$ high, the foot is $30 \mathrm{~cm}$ thick, the body is $20 \mathrm{~cm}$ thick and it is $170 \mathrm{~cm}$ wide. In the upper part there are at least 18 niches, each of which is $20 \mathrm{~cm}$ high, $15 \mathrm{~cm}$ wide and $20 \mathrm{~cm}$ thick. It is the length of the building that probably leads to the name sanggah dawa. The building materials used for building sanggah dawa are bricks, and today also concrete and wood. Formerly, such structures were made entirely of bamboo. 


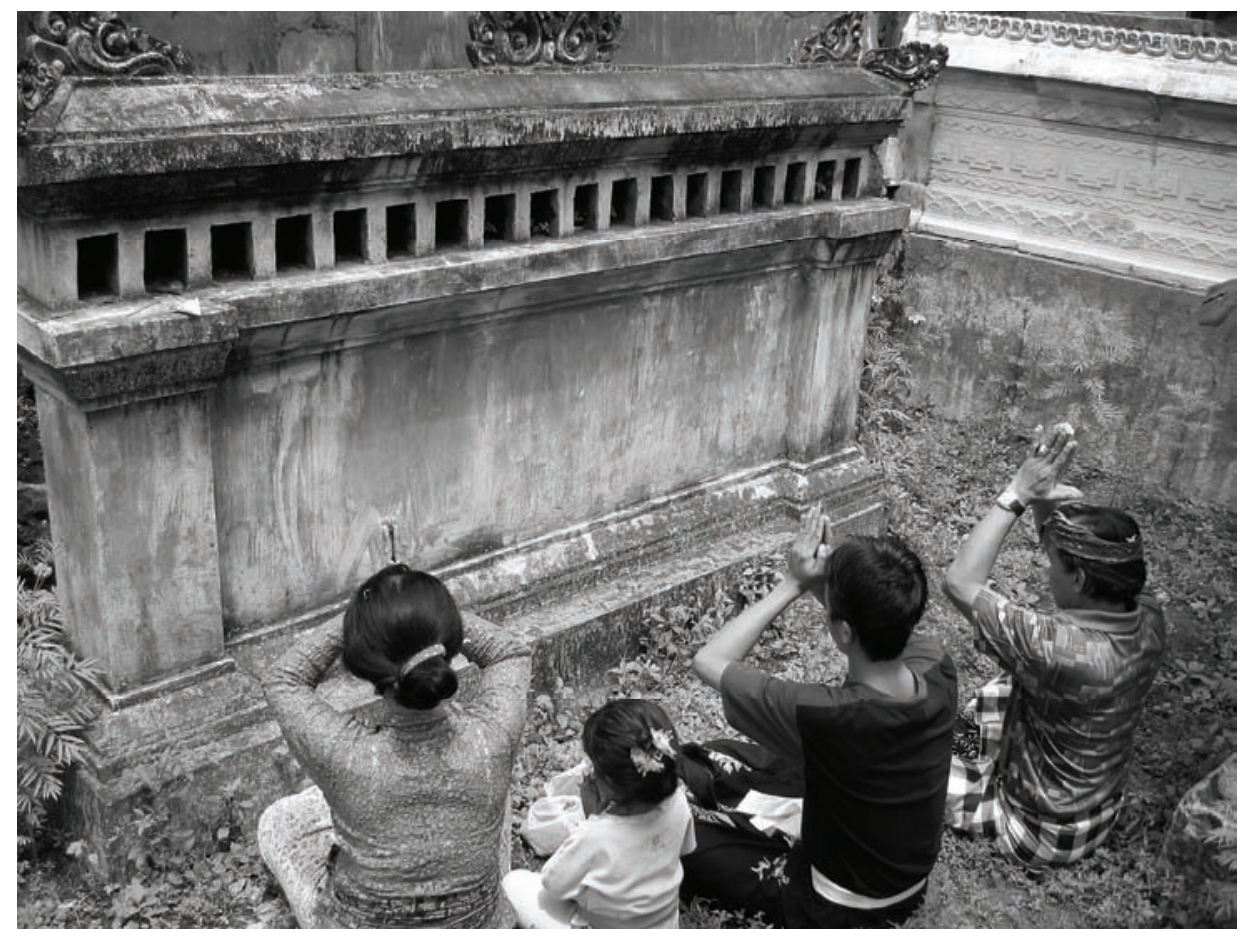

Photo 1: Worshipping in front of a sanggah dawa made of red bricks and covered with concrete; note the 18 niches. Photo: Brigitta Hauser-Schäublin 2007.

Based on information provided by I Nyoman Tisna, a well-known woodcarver and architect, sanggah dawa is the main structure of a family temple (sanggah). I Nyoman Tisna is a member of the Bujangga-Clan (Bujangga-Waisnawa). Seven generations ago, the forefather of Nyoman Tisna fled from Pintu village, which today no longer exists (see Hauser-Schäublin this volume), to Pacung and settled there. Pintu village was at that time attacked by "wild animals of the bush" probably a metaphor for enemies - and completely wiped out. Nyoman Tisna's ancestor escaped the killings, together with an elder brother who sought refugee in Sembiran and settled there. Still today, the descendants of these refugees in Sembiran and Pacung are closely related. Today, there are four Bujangga households in Pacung and each has its own sanggah dawa. Since members of other clans in Pacung also have sanggah dawa, we can assume that this type of shrine is more typical of Pacung village than of a single clan such as the Bujangga. It needs to be pointed out that the descendants of Bali Mula, or Aboriginal Balinese, in Pacung do not have a sanggah dawa in their household temple.

The specific feature of sanggah dawa is that it displays at least 18 niches. In addition, Nyoman also stated that the existence of the 18 niches cannot be separated 
from the belief system of the local community, that is, they believe in God and the ancestors' souls that control human life. The souls of their ancestors are called Ratu Tempekan Batur. This is the personification of the unified god and the purified souls of their ancestors, including those of the village founders. Altogether, there are 18 deities. They are:

Table 1: List of Gods and Places of Origin

\begin{tabular}{|c|c|c|}
\hline & List of Gods & Place of Origin \\
\hline 1) & Ratu Gede Penataran & \multirow{4}{*}{$\begin{array}{l}\text { These deities are located in the Pura Desa/Bale Agung, } \\
\text { Pacung (Village Temple). }\end{array}$} \\
\hline 2) & $\begin{array}{l}\text { Ratu Gede Maduwe } \\
\text { Karang }\end{array}$ & \\
\hline 3) & $\begin{array}{l}\text { Ratu Gede Duuring } \\
\text { Akasa }\end{array}$ & \\
\hline 4) & $\begin{array}{l}\text { Ratu Ayu Pangentel } \\
\text { Gumi }\end{array}$ & \\
\hline 5) & $\begin{array}{l}\text { Ratu Gede Bhujangga } \\
\text { Sakti }\end{array}$ & This deity's home is Pura Jati at the Batur Lake. \\
\hline 6) & Ratu Ayu Gunungsari & This deity's home is Pura Penulisan. \\
\hline 7) & $\begin{array}{l}\text { Ratu Ngurah Gunung } \\
\text { Lebah }\end{array}$ & This deity's home is Pura Desa Batur. \\
\hline 8) & $\begin{array}{l}\text { Ratu Sesuhunan } \\
\text { Gunung Sinunggal }\end{array}$ & This deity's home is Pura Pucak Sinunggal. \\
\hline 9) & $\begin{array}{l}\text { Ratu Sesuhunan } \\
\text { Gunung Mas }\end{array}$ & \multirow[t]{2}{*}{$\begin{array}{l}\text { These deities are located in the Pura Desa / Bale Agung, } \\
\text { Pacung. }\end{array}$} \\
\hline 10) & Ratu Bagus Nengah & \\
\hline 11) & $\begin{array}{l}\text { Ratu Gede Gunung } \\
\text { Agung }\end{array}$ & $\begin{array}{l}\text { This deity is located on Bali's holiest mountain, Gunung } \\
\text { Agung. }\end{array}$ \\
\hline 12) & Ratu Puseh Duur & $\begin{array}{l}\text { This deity represents the origin of the village that has a } \\
\text { shrine with a pagoda roof in the Village Temple. }\end{array}$ \\
\hline 13) & Ratu Gede Pemaksan & $\begin{array}{l}\text { This deity represents the village community of Pacung; } \\
\text { there is a special shrine in the Village Temple. }\end{array}$ \\
\hline 14) & Ratu Ngurah Bolot & $\begin{array}{l}\text { This deity's home is the Pura Sang Hyang Marek, a temple } \\
\text { on the sea shore used by both Sembiran and Pacung. }\end{array}$ \\
\hline 15) & $\begin{array}{l}\text { Ratu Ngurah Sisin } \\
\text { Segara }\end{array}$ & This deity has also its home in the Pura Sang Marek. \\
\hline 16) & Ratu Gede Dasar & This deity has its home in the Pura Dalem (Death Temple). \\
\hline 17) & Ratu Gede Dikumpi & $\begin{array}{l}\text { This deity, representing the forefathers mainly of aboriginal } \\
\text { Balinese no longer has a definite home; the shrine it once } \\
\text { had in the Village Temple has been abandoned. }\end{array}$ \\
\hline 18) & Ratu Bagus & $\begin{array}{l}\text { This deity has its home in Pacung's Pura Ulun Siwi (Tegal } \\
\text { Suci) Temple. }\end{array}$ \\
\hline
\end{tabular}


Each deity subsumed under the name Ratu Tempekan Batur is worshipped through the niches available at the sanggah dawa. The numbers above and the corresponding deities start according to the niches in the shrine, starting on the left hand side, which is the eastern side. Most of the deities (except Ratu Gede Dasar) subsumed under the name Ratu Tempekan Batur have also a seat in the Pura Puseh/Bale Agung Temple in Pacung and worshipped there by the village community: the deities numbered 1 to 3 share (ngerob) a closed shrine (palinggih gedong); this shrine is located in the most eastern mountainward corner of the Village Temple. The deities numbered 4 to 6 share a shrine in the Village Temple, as do those numbered 7 to 9; 10 and 11 are housed together in yet another shrine again. All other deities have an individual shrine.

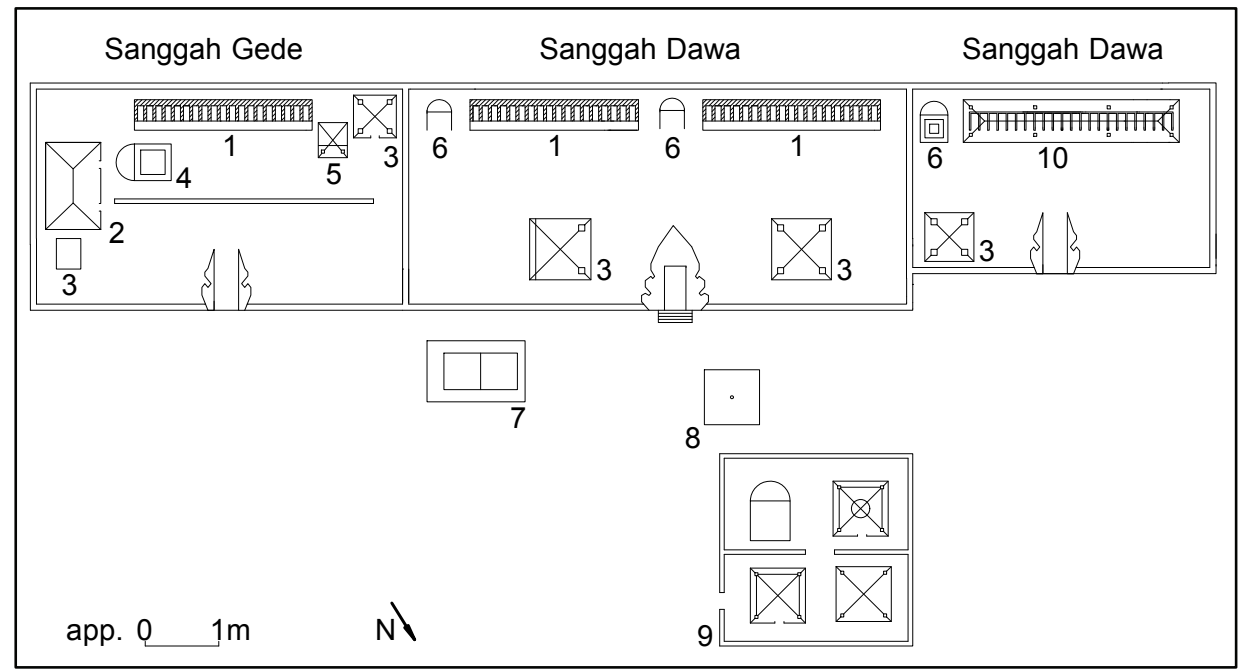

Figure 1: Four sanggah dawa of different lineages of one clan. The one at the furthest right is made of wood, the others of red brick and concrete. No. 1: Sanggah dawa; No.2: Shrine for Sang Hyang Tiga Sakti; No. 3: Piasan; No. 4: Shrine for I Ratu Gede Bujangga Sakti; No. 5: Shrine for I Ratu Susunan Gunung Mas; No. 6: Kemulan, No. 7: Istana Kembar; No. 8: Penunggun Karang; No. 9: Paibon.

The names of the gods and goddesses classified as Ratu Tempekan Batur in the sanggah dawa show that each household temple is closely interwoven with the deities and main temples of Pacung village. The sanggah dawa is more or less a representation of all the major village gods at the individual household. Some of the deities are closely associated with Pacung as a localized community, such as Ratu Gede Penataran, Ratu Gede Maduwe Karang, Ratu Gede Duuring Akasa, Ratu Bagus Nengah, Ratu Puseh Duur, Ratu Gede Pemaksan, Ratu Gede Dasar and Ratu Gede Dikumpi. Others show far-reaching relationships, those to the temples 
at Penulisan and Batur in the central mountain range. A further group of deities are related to sacred places in the neighbourhood, such as the mountain sanctuary of Sinunggal near the village of Tajun or the sea temple of Sang Hyang Marek. The sanggah dawa is an important sacred site in the household temple; usually there is an additional shrine beside the sanggah dawa which is dedicated to Ratu Gede Kemulan, the god controlling the origin of life.

Apart from the sanggah dawa, Nyoman Tisna's clan in Pacung also has a sanggah gede and a paibon where the Unified God (Sang Hyang Tiga Sakti) and the purified forbearers of the clan are worshipped.

A closer examination of sanggah dawa revealed that some have more niches than 18. The one owned by Nyoman Tisna has 22 niches; two sanggab dawa of his closest relatives have nine and one 18 niches. Why do some have more recesses than others? Based on the information obtained from Made Wiryana, the significance of sanggab dawa cannot be separated from the life-cycle ceremonies conducted by a family head.

The members of the krama desa (village association of the Hindu-Balinese) are all married. As family head, a man has to carry out life-cycle rituals as part of the life-long process of purifying himself. There are nine stages in the religious ceremonies that he has to conduct in order to be able to add a further niche to the sanggah dawa. The first stage takes place when he is newly married; this ritual is called mragat. The philosophical meaning of this ceremony is a request for purification and safety for him and his wife in carrying out grahsta asrama (married life).

A few days later, the ceremony mragat is followed by melis, namely a purification ceremony which is performed in the yard, at the house (bale), and in front of the shrine where Ratu Ayu is worshipped by means of holy water (tirta). Then another ceremony follows called maklaci, which is carried out at the Village Temple on the day of the new moon (tilem). This ceremony implies that the man and his wife are socially and legally acknowledged as a new household. The couple now becomes a member (krama) of the desa pakraman; the husband joins the male and his wife the female organization. Maklaci is the formal admission to the sociopolitical and religious village association. To be member of the desa pakraman means to have rights and duties towards the village and its community. On another level, the couple will be also responsible for obligations towards the village temples of Pacung.

The Bendesa Pacung (the leader of ceremonies), I Wayan Liarsa, stated that today the ceremony of maklaci can be carried out any time after the ceremony of melis is finished. There is no longer a special day for maklaci. This arrangement was made because many villagers work away from the village. They have limited time and are, therefore, given time off so that the ceremony can be carried out.

The next ceremony is mapanyari, meaning the offering of devotion at a village temple or at the household temple. In this ceremony an offering of pork is made, called bhakti daar. The next stage of the ceremony is macicipan with an offering in 
the form of a complete pejati which should be presented at two holy places, one at the wife's father temple and the other at Bali Mula family shrines.

If the new family has developed and economically strengthened, the next ceremony to be conducted is bhakti ngaturin bulu geles. This ceremony is directed to Ratu Dalem Tajun (the village is located on the hills) through a place called Pengaturan, which is located on Sembiran territory up the hills and is about two kilometres from Pacung. The ceremony involves six male calves (godel) (two for Dalem Tajun, two for Dalem Bayad and two for Ratu Bolot) with banten pengikutan (a kind of offering) in the shape of one roasted suckling pig (babi guling). The six calves are brought to Pengaturan where they are butchered following a ceremony. Half the meat is used for ceremonial purposes and the other half is consumed together at the location.

The next ceremony is panyicipan consisting of an offering called salaran, a mixture of all kinds of agricultural products such as fruits, tubers, chicken and ducks; this is offered to the gods at Julah's village temple. The next ceremony is called the second bhakti ngaturan and is performed at the Dalem Temple and Dalem Bayad Temple at Tajun. The offerings used at this ceremony are the same as those when bhakti ngaturan bulu geles is conducted, but the roasted suckling pig has to be male. The next ceremony consists of offering bhakti aturan, whose form is identical with that of the second bhakti ngaturan. This is the whole cycle of rituals performed after marriage. It shows on the one hand the extent to which Pacung is interconnected with the neighbouring villages of Tajun, Julah and Sembiran, the latter two being villages from which Pacung is said to be an offshoot. From a comparative perspective, the ceremonial stages mentioned above and their names display many similarities with those in Sembiran (see Riemenschneider and Hauser-Schäublin 2006:39-41).

The meaning of the additional niches on the sanggah dawa can be identified by making a comparison with Hinduism as a philosophy in particular its teachings related to the stages of life and the objectives of human life. In Hinduism, the stages of human life can be classified into four. They are: catur asrama consisting of the learning era (brahmacari), the married era (grhastha), the religion learning era, and, lastly the freeing of the individual from earthly things (vanaprastha) in order to achieve moksa (the heaven - the eternal life). There are also four objectives of life. They are: cultivating religious truth, seeking after wealth (artha), seeking after pleasure (kama), and seeking after eternal life (moksa). The goal of the learning era (brahmacari) is the truth (dharma), the goal of married life (grhasta) is artha (wealth) and the goal of artha, kama and vanaprasta and saniasin is moksa (eternal life).

The family head who has been able to conduct the ceremony of bhakti aturan bulu geles is said to have reached the stage of vanaprastha. The reason is that he has been able to release himself from being attached to earthly pleasures in the forms of artha and kama. Moreover, the family head who has been able to conduct the second bhakti aturan up to the last ceremony after going through bhakti panyipan is 
said to have reached the life stage of saniasin asrama. In Hinduism, if someone has been able to carry out the stages of life and to realize them in his or her daily life well and truthfully, he is stated to be able to achieve his final life goal, that is, eternal life, which can be achieved when still alive and is called mukti. If this assumption is true, he will be given high social status, since he has been able to carry out all forms of devotion (bhakti) and has shown capability in all aspects of life.

\section{Sites of Purified Ancestors' Souls}

The fulfilment of these ritual obligations is a precondition for the performance of a further large ceremony called ngeneman sanggah. This ritual aims at freeing a whole generation (or two) of ancestors (both male and female) from the last ties to earthly life. This large ritual enables the head of the family to add a further niche (rong) to the sanggah dawa. The souls of the ancestors thus freed will then take seat in this additional recess; they are worshipped there by their descendants. Nyoman Tisna's grandfather was the last member of the family who was able to perform this large-scale ceremony. The 22 recesses of Nyoman Tisna's sanggah dawa give evidence of the fact that so far four of his ancestors have carried out ngeneman sanggah since his shrine has 22 niches instead of the 18. Ngeneman sanggah takes place at the family temple; the offerings consist of six pigs. This final ceremony is also a big feast to which all village organizations are invited: all the members of the desa pakraman, sekaa gong (the gong orchestra), sekaa baris (a group of warrior dancers), sekaa rejang (a group of female dancers performing rejang [dance]) and sekaa legong (a group of female dancers performing legong). Among the six pigs, three serve as offerings in the ceremony; two are prepared as a meal for the invited village members and sekaa, and one is used for banten pabangkitan (a kind of offering).

If all the steps of the ceremonies have been gone through without curtailment, the family head is held to have fulfilled his swadharma (holy obligations) as a Hindu follower and is allowed to add one more niche to his sanggah dawa. If a man dies before he can fulfil all the ceremonies, his son has to continue them on behalf of his father. The son cannot complete the life cycle rituals for himself before those of his father have come to an end. It is the son's duty to complete the ritual cycle of his father first. If the son disregards this duty, he is assumed to have broken the norms and to be sinful (alpaca guru rupaka). Unless a man has fulfilled all these duties he is unable to perform ngeneman sanggah.

From what has been described above, it can be concluded that further niches on the sanggah dawa can be added only if all the holy obligations of the preceding and the present generation (swadharma) have been completely fulfilled. In addition, it also means that the family head has succeeded in raising enough money for these expensive ceremonies. Not everybody can put on big and complicated 
ceremonies, only those that are socially, economically and politically capable of doing so.

The attempt of a family head to add a further niche to his sanggah dawa can be viewed as an ongoing competition between family heads. At the same time ngeneman sanggah is a public ceremony organized by a single household. All the covillagers are invited and served with food; therefore, this ceremony constitutes a kind of on-going exchange in the village, continuously producing new relationships of exchange (reciprocity) by giving, taking and owing among the village members. What is given in the form of offerings to the gods/ancestors is classified as niskala (immaterial) and what is later served for the village members is classified as sekala (material). The process of providing niskala and sekala is seen as one single achievement and contributes to the prestige of the person who performed it.

\section{Conclusion}

Sanggah dawa is a particular type of shrine in a household temple. This building constitutes a special form of Bali's cultural heritage, a testimony of Bali's moral values, its history, aesthetics and its symbols. In north Bali, the sanggah dawa represents a typical feature of Pacung village. sanggab dawa serves as a particular place for the worship of God in all his aspects, the power of nature and the purified souls of the ancestors. Such a shrine is always located in the most pure direction of the household temple, which is mountainward. The name of Ratu Tempekan Batur - a collective name for all deities and purified ancestors - accounts for all the divinities worshipped in this row of 18 and more niches. The shrine comprises at least 18 small niches; those are sites where the major deities of the village are worshipped. Further recesses are sites of the purified ancestors' souls that are worshipped there. A further niche may be added only after the completion of all life cycle rituals; it testifies to the fact that the head of the family has already completed swadharman - rituals whose goal is purification and the expression of gratitude towards God. To add a further recess another expensive ceremony to which all villagers are invited is required. This ceremony, ngeneman sanggah, is part of a prestigious exchange system within the village that conveys at the social level high status to the head of the household who has carried them out. Usually only every second or third generation is capable of performing such a ritual. To all his descendants, the existence of more than 18 niches on the sanggab dawa is an object of pride. At the level of religion, such a completion empowers a person to perform all types of rituals without any further restriction. 


\section{References}

Ardana, I Gusti Gede

1986 Unsur Megalitik dalam Hubungan dengan Kepercayaan di Bali. In: Makalah

Pertemuan Ilmiah Arkeologi, Jakarta, 1980.

Hendropuspito, D.

1983 Sosiologi Agama. Jakarta: Kanisius.

Koentjaraningrat

1980 Sejarah Teori Antropologi, Vol. I. Jakarta: Universitas Indonesia Press.

Riemenschneider, Christian und Brigitta Hauser-Schäublin

2006 „....Yang Hidup di sini, Yang Mati di sana“: Upacara Lingkaran Hidup di Desa

Sembiran, Bali (Indonesia). Göttinger Studien zur Ethnologie, Bd. 15. Münster:

LIT-Verlag.

\section{List of Informants}

I Nyoman Tisna, 56, Banjar Kubuanyar, Pacung, Retired Government Civil Servant; Wood Carver and Architect.

I Wayan Liarsi, 70, Banjar Kubuanyar, Pacung, Bendesa Adat

I Made Wiryana, 53, Banjar Kubuanuyar, Pacung, Head of Banjar Kubuanyar, Pacung 